\title{
Quantitative analysis of rat adipose tissue cell recovery, and non-fat cell volume, in primary cell cultures
}

\author{
Floriana Rotondo ${ }^{1,2}$ ， María del Mar Romero ${ }^{1,2,3}$ ， Ana Cecilia Ho-Palma ${ }^{1}$, Xavier Remesar ${ }^{1,2,3}$, José Antonio \\ Fernández-López ${ }^{1,2,3}$, Marià Alemany ${ }^{\text {Corresp. } 1,2,3}$ \\ ${ }^{1}$ Department of Biochemistry and Molecular Biomedicine, University of Barcelona, Faculty of Biology, Barcelona, Spain \\ 2 Institute of Biomedicine, University of Barcelona, Barcelona, Spain \\ 3 CIBER OBN, Barcelona, Spain \\ Corresponding Author: Marià Alemany \\ Email address: malemany@ub.edu
}

Background. White adipose tissue (WAT) is a complex, diffuse, multifunctional organ which contains adipocytes, and a large proportion of fat, but also other cell types, active in defence, regeneration and signalling functions. Studies with adipocytes often require their isolation from WAT by breaking up the matrix of collagen fibres, however, it is unclear to what extent adipocyte number in primary cultures correlates with their number in intact WAT, since recovery and viability are often unknown.

Experimental design. Epididymal WAT of 4 young adult rats was used to isolate adipocytes with collagenase. Careful recording of lipid content of tissue, and all fraction volumes and weights, allowed us to trace the amount of initial WAT fat remaining in the cell preparation. Functionality was estimated by incubation with glucose and measurement of glucose uptake and lactate, glycerol and NEFA excretion rates up to $48 \mathrm{~h}$. Non-adipocyte cells were also recovered and their sizes (and those of adipocytes) were also measured. The presence of non-nucleated cells (erythrocytes) was also estimated.

Results. Cell numbers and sizes were correlated from all fractions to intact WAT. Tracing the lipid content, the recovery of adipocytes in the final, metabolically active, preparation was in the range of 70$75 \%$. Cells showed even higher metabolic activity in the second than in the first day of incubation. Adipocytes were $7 \%$, erythrocytes $66 \%$ and other stromal (nucleated cells) $27 \%$ of total WAT cells. However, their overall volumes were, $90 \%, 0.05 \%$, and $0.2 \%$ of WAT. Non-fat volume of adipocytes was $1.3 \%$ of WAT.

Conclusions. The methodology presented here allows for a direct quantitative reference to the original tissue of studies using isolated cells. We have found, also, that the "live cell mass" of adipose tissue is very small: about $13 \mu \mathrm{L} / \mathrm{g}$ for adipocytes and $2 \mu \mathrm{L} / \mathrm{g}$ stromal, plus about $1 \mu \mathrm{L} / \mathrm{g}$ blood (the rats were killed by exsanguination). These data translate (with respect to the actual "live cytoplasm" size) into an extremely high metabolic activity, which make WAT an even more significant agent in the control of energy metabolism. 
5 Quantitative analysis of rat adipose tissue cell recovery, and non-fat cell 6 volume, in primary cell cultures

8 Floriana Rotondo 1,2, María del Mar Romero 1,2,3, Ana Cecilia Ho-Palma 1, Xavier Remesar 1,2,3, 9 José Antonio Fernández-López ${ }^{1,2,3}$ and Marià Alemany 1,2,3

${ }^{1}$ Department of Biochemistry and Molecular Biomedicine, Faculty of Biology University of Barcelona, Barcelona, Spain

$12^{2}$ Institute of Biomedicine, University of Barcelona, Barcelona, Spain

$14{ }^{3}$ CIBER-OBN Research Net, Barcelona, Spain

Author for correspondence:

Dr. Marià Alemany. Department of Biochemistry and Molecular Biomedicine, Faculty of Biology, University of Barcelona; Av. Diagonal, 643; 08028 Barcelona, Spain. Tel: 34934034 606; E-mail: malemany@ub.edu 


\section{Introduction}

White adipose tissue (WAT), which has been defined as the adipose organ (Cinti 2001), is dispersed in a large number of locations, in which its basic energy storage activity is complemented by many other physiological functions (Alemany \& Fernández-López 2006). In any case, its main acknowledged role is to contribute to the defense of energy homoeostasis, helping to control glucose (Sabater et al. 2014), lipid (Deschênes et al. 2003; Wang et al. 2016), and amino acid (Arriarán et al. 2015a) metabolism overall. It is responsible for an important share of the control of whole body energy availability (Hall et al. 2009+; Choe et al. 2016), and acts as a platform for the immune system, being actively implicated in processes of protection and repair (Parker \& Katz 2006; Dixit 2008). The complex (and varying) mixture of cell types in WAT depots largely determines and modulates these functions as part of its adaptability (Vielma et al. 2013; Oishi \& Manabe 2016).

Most of WAT volume is taken up by a relatively small number of large cells, the mature adipocytes, which are generally considered the genuine cells of this tissue and thus the main target for the fight against obesity (Nawrocki \& Scherer 2005). However, most of the adipocyte volume is filled by (triacylglycerol) energy reserves (Kotronen et al. 2010). This can be extended, obviously in similar proportions, (often higher than $80 \%$ ) to the WAT/ adipose organ taken as a whole. This is a variable but significant share of total body weight $(5-50 \%)$ in humans and most animal phyla. The rest of WAT cells are loosely called stromal, despite most of them not being actually connective tissue cells (da Silva Meirelles et al. 2015). In this text, we will use the general term "stromal cell" to refer to all WAT cells different from fat-laden adipocytes.

The stromal fraction of WAT is made up of immune system, stem, blood, endothelial, true stromal and other types of cells, with relevant functions in the maintenance of adipocyte energy homoeostasis (Sadie van Gijsen et al. 2012), defense (Hill et al. 2014), regeneration (Domergue et al. 2016), differentiation (Gimble et al. 2011; Mitterberger et al. 2014) and others (Sumi et al. 2007; Takahara et al. 2014). Many of these functions become critical under conditions of inflammation (Lee 2013), changing the cell composition and overall WAT metabolism (Lolmède et al. 2011; Cignarelli et al. 2012). Adipocytes, despite their small numbers (but huge volume due to their fat stores), have been intensely studied as "representative" of WAT (Leonhardt et al. 1978). To study their metabolic or regulatory capabilities, the cells are isolated from WAT masses and studied using primary (Garvey et al. 1987) or immortalized (Tordjman et al. 1990) cell cultures. The information obtained is often taken as directly representative of WAT in vivo, in spite of the large number of factors that are 
64

65

66

67

68

69

known to rebut this excessively simplistic approach (O'Brien et al. 1996), including the ordeal of cell isolation (Thompson et al. 2012).

When dealing with WAT, the data obtained from most experiments is deeply conditioned by the methodology used, i.e. isolated cells, tissue pieces or slices, or in vivo functional analyses. Seldom can we obtain quantitative data which could be referred to the live tissue. Comparison of different locations, individuals, metabolic or pathologic conditions is severely hampered by the size of fat depots (Cinti 2001; Wronska \& Kmiec 2012), the varying proportion of adipocyte/stromal cells (in fact, only when the latter are actually taken into account (Pasarica et al. 2009)) and the blood flow/oxygen and substrates' availability (Mjös \& Akre 1971). Quantification of adipocyte recovery from whole tissue samples, and the analysis of the proportion of "live" cell space in the tissue are necessary steps for direct comparison of data from different sources. Unfortunately, cell number is dependent on the method of quantification used, and is logically affected by cell volume. The proportion of fat in the tissue and cells also proportionally "reduces" the live-cell mass. This is further confounded by the direct estimation of cell numbers via DNA analysis which (at least in mammals) would not detect the number of erythrocytes, but would detect numbers of small hematopoietic cell (Luche et al. 2015) macrophages and lymphocytes (Sell \& Eckel 2010). The latter non-adipocyte populations would then be counted as "adipocytes", despite having a volume about $10^{5}$-fold smaller.

Referring cell or tissue experimental data to protein content may be a fair index for comparison, but the large presence (also deeply varying depending on location (Alkhouli et al. 2013)) of extracellular fibrous proteins, such as collagen (Liu et al. 2016) also modifies the quantitative evaluation of the metabolically active fraction of the tissue; this fraction is also deeply affected by obesity and inflammation (Li et al. 2010).

In the present study, we have devised a method for the estimation of actual adipocyte recovery of viable adipocytes with respect to WAT mass based on the unique presence of large amounts of fat in them. We have also intended to present an estimation of the size of the metabolically active WAT cell mass with respect to the mass/ volume of the tissue. We used, as reference, the epididymal WAT fat pads of non-obese healthy adult rats (to limit the known effects of inflammation on WAT cell profile). This location is considered to be one of the less metabolically active (Arriarán et al. 2015b), and is widely used for "representative" WAT adipocyte function for its size, easy dissection and absence of contamination by neighboring tissues.

\section{Materials and Methods}




\section{Rats and housing conditions}

All animal handling procedures and the experimental setup were in accordance with the animal handling guidelines of the corresponding European and Catalan Authorities. The Committee on Animal Experimentation of the University of Barcelona specifically authorized the procedures used in the present study.

Male Wistar rats (Harlan Laboratory Models, Sant Feliu de Codines, Spain), 18-week old, weighing $435 \pm 84 \mathrm{~g}$ (mean, sd), were used after a 2 -week acclimation period in a controlled environment. The animals were kept in two-rat cages with wood shards as bedding material, at $21-22^{\circ} \mathrm{C}$, and $50-60 \%$ relative humidity; lights were on from 08:00 to 20:00. They had unrestricted access to water and standard maintenance rat chow (Harlan \#2014).

\section{Isolation of adipocytes}

The rats were killed, under isoflurane anesthesia, at the beginning of a light cycle, by exsanguination from the exposed aorta, using dry-heparinized syringes. The rats were rapidly dissected, taking samples of epididymal WAT, used immediately for adipocyte isolation. This procedure followed, essentially that described by Rodbell (Rodbell 1964). In short, tissue samples were weighed, immersed in the digestion medium described below, and cut in small pieces with scissors. Samples were incubated, at $37^{\circ} \mathrm{C}$ in a shaking bath for 60 min, with 2.5 volumes of Krebs-Henseleit buffer $\mathrm{pH} 7.4$, containing $5 \mathrm{mM}$ glucose, $0.1 \mu \mathrm{M}$ adenosine (SigmaAldrich, St Louis MO USA) (Honnor et al. 1985), and $10 \mathrm{~g} / \mathrm{L}$ lipid-free bovine serum albumin (Merck-Millipore, Billerica, MA USA). This was complemented with $3.5 \mathrm{mkat} / \mathrm{L}$ collagenase (LS004196, type I, from Worthington Biomedical, Lakewood NJ USA). The collagenasecontaining digestion buffer was prepared in the cold room $\left(4^{\circ} \mathrm{C}\right)$, and was used within $1 \mathrm{~h}$.

At the end of the digestion process (carried at $37^{\circ} \mathrm{C}$ ), the suspensions were gently sieved using a double layer of nylon mesh hose [plain commercial sheer tight stocking; $90 \%$ polyamide, $10 \%$ elastomer, parallel woven with 15 den cylindrical single-filament threads; with approximate mean -flexible — pores in the range of $300 \mu \mathrm{m}$ ], which retained vessel fragments and (eventually) undigested tissue pieces. The smooth crude suspension of isolated cells was left standing for 5 minutes on stoppered polypropylene syringes (\#SS+10ES1, Terumo, Tokyo, Japan), held vertically, at room temperature $\left(22-24{ }^{\circ} \mathrm{C}\right)$. The adipocytes floated to form a defined upper layer. Then, the lower aqueous fraction was slowly drained off, capping again the syringe to retain the adipocytes. The cells were washed this way three times, using 2.5 volumes of the buffer each time. Before re-suspending the cells in it, the buffer was subjected to $30 \mathrm{~s}$ vortexing, to allow for equilibration with air oxygen. The final supernatant fraction contained intact adipocytes and a thin layer of free fat from broken cells. After the final washing, $400 \mu \mathrm{L}$ aliquots of the cells' fraction were taken for incubation. The samples were slowly extracted from the 
133

134

135

136

137

138

139

140

141

142

143

144

145

146

147

148

149

150

151

152

153

154

155

156

157

158

159

160

161

162

163

164

165

166

167

central part of the adipocytes' layer, trying not to disturb the thin-floating lipid layer. The cells were manipulated and maintained at room temperature for a time as short as possible, and used immediately after the final washing.

Stromal cell space in the isolated cell suspension, used to relate their numbers and volumes to initial tissue weight, was considered the sum of the volume of the lower phase of adipocyte separation in the syringes, plus the volume of the adipocyte phase to which the volume of adipocytes (calculated from cell numbers and volumes) was subtracted. Obviously, the first separation of adipocytes and stromal cells left a high number of the latter mixed with adipocytes. The three successive washings resulted in the presence (calculated) of, at most, $0.1 \%$ of the initial stromal cells in the final washed adipocyte fraction (down from an initial $7.3 \%$ ). This assumption does not take into account stromal cells bound, retained or attached to the larger adipocytes.

\section{Estimation of the efficiency of adipocyte extraction}

Practically all fat in WAT is limited to adipocytes. All types of cells contain lipids, mainly as membrane components; the small size of the combined mass and their density do not alter the cells' density and, consequently their buoyancy. A few types of cells, i.e. macrophages, foam cells and differentiating preadipocytes may contain sizeable amounts of fat, but they only appear under precise physiological conditions (foam cells, differentiating preadipocytes) and their numbers and size (and thus their combined content of fat) make their contribution small (negligible in the present case). All other cells do not have sufficient lipid to generate enough floatability to allow their separation from the rest of cells by just standing -i.e. at $1 \mathrm{x} g-$ for five minutes. We used this differential fat content to establish an approximate estimation of the efficiency of the digestion-extraction procedure for adipocyte isolation described above, simply by estimating the recovery of fat from the intact tissue to a preparation containing only viable functional cells.

A sample of just dissected WAT was divided in two parts, one was processed to obtain washed adipocytes as described above, and the other was divided in several aliquots, used to measure the water (dry weight after $24 \mathrm{~h}$ at $90{ }^{\circ} \mathrm{C}$ ) and lipid content. To measure lipids, fragments of about $300 \mathrm{mg}$ of intact tissue were weighed and extracted with trichloromethane: methanol $(2: 1 \mathrm{v} / \mathrm{v})$ (Folch et al. 1957). The resulting values were used to establish the proportion of lipids in the intact tissue. Using this method as originally described, most of membrane lipids were not extracted (Rose \& Oklander 1965; Eder et al. 1993), but the recovery of WAT-vacuole lipids (i.e. fat, essentially triacylglycerols) was quantitative. The weights of the lipids present in the fat layer on top of the cells' suspension (washed and essentially free of stromal cells, as explained above), and those of stromal cells' fraction and extraction debris were measured. The 
168

169

170

171

172

173

174

175

176

177

178

179

180

181

182

183

184

185

186

187

188

189

190

191

192

193

194

195

196

197

198

199

200

201

202

weight of the recovered adipocyte fraction and their water and lipid content were also estimated, thus obtaining the total weight of lipid present in the isolated adipocytes.

The density of WAT was estimated using tightly capped tubes, which were weighed both dry and completely full of deionized water at $20^{\circ} \mathrm{C}$. The net weight of water was used to calculate the volume of the tube. The process was repeated including weighed 300-500 $\mathrm{mg}$ pieces of intact WAT in the tubes and completely filling them with water (nevertheless, no different values were obtained using pieces of 200 to $1000 \mathrm{mg}$ ). The difference in weight of the tubes with and without WAT samples allowed us to calculate the volume of the samples; their density was estimated from the volume and weight. Other samples of WAT were used to extract its lipid as described above. The density of the extracted lipid was estimated using the same procedure using cold-solidified fat samples.

The weight of lipid extracted from the adipocyte preparation was compared with the initial weight and the actual proportion of lipid present in the intact tissue, after discounting the weight of debris eliminated during the process of extraction. Lipid in the stromal cell fraction was negligible, statistically not different from zero.

\section{Measurement of isolated cell parameters}

A known volume of the suspension of adipocytes was introduced in a Neubauer chamber (\#717810 Neubauer improved bright line, Brand Gmbh, Wertheim, Germany). Using an inverted microscope, four fields (following a pre-established selection pattern) were photographed at low power (Figure 1). Four samples of each adipocyte suspension were inspected, taking 16 photographs from each. Cells were identified, counted, and their diameters analyzed (under the conditions used, all cells adopted a spheroid form), using the FIJI ImageJ software (http://imagej.nih.gov/ij/), following a simple procedure (Baviskar 2011). The data were computed (range, mean and SD for diameter, cell volume and number, including their combined volume). In this experiment, the final range of counted cells (mean, SD) was $96 \pm 10 \mu \mathrm{m}$ in diameter (when assuming the form of a sphere), i.e. $475 \pm 147 \mathrm{pL}$ in volume. Figure 2 shows a representative example of the range of cell sizes obtained using this procedure on epididymal WAT.

Non-nucleated cells (essentially red blood cells: RBCs) were identified by their smaller size (in the fL range) using the Scepter 2.0 cell counter (EDM Millipore Corp, Billerica, MA USA) hand-held cell sizer. Total stromal cells, (i.e. including RBCs) were analyzed for each sample using two different cell-range tips for the Scepter: Sensor 40, for 3-18 $\mu \mathrm{m}$ particles' size (PHCC40050, Merck Millipore, Darmstadt, Germany) and Sensor 60, for 6-36 $\mu \mathrm{m}$ particles' size (PHCC60050, Merck MIllipore). The data for both ends of the superimposed size graphs were taken as final values, and those in the overlapping zone were used taking in both series of data 
203

204

205

206

207

208

209

210

211

212

213

214

215

216

217

218

219

220

221

222

223

224

225

226

227

228

229

230

231

232

233

234

235

236

against diameter. After the data were arranged, the measured volumes were plotted and the data were statistically analyzed.

Using stromal cell fraction samples from all rats tested, a cytometric flow analysis (Figure 3) was performed to distinguish the proportion of small non-nucleated cells (i.e. red blood cells) from those nucleated and either dead or viable. The analyses were done using a FacsAria I SORP sorter (Beckton-Dickinson, San Jose CA USA). The cells were stained with propidium iodide (Sigma-Aldrich) and Syto-13 (Life Technology, Thermo-Fisher Scientific, Waltham, MA USA) used to estimate the proportion of non-nucleated red blood cells in the samples as a percentage of total stromal cells. We used this value to estimate the presence of blood cells in the whole tissue and stromal cell counts, incorporating these data in the calculations.

Cell viability

We analyzed the functionality of the cells checking their metabolic integrity along a 2day incubation study. We used 12-well plates (\#CLS3513 Costar, Sigma-Aldrich) filled with 1.7 ml of DMEM (\#11966-DMEM-no glucose; Gibco, Thermo-Fisher Scientific, Waltham MA USA), supplemented with $30 \mathrm{~mL} / \mathrm{L}$ fetal bovine serum (FBS, Gibco). The medium (Romero et al. 2015) also contained $25 \mathrm{mM}$ hepes (Sigma-Aldrich), $2 \mathrm{mM}$ glutamine (Lonza Biowhittaker, Radnor, PA USA), $1 \mathrm{mM}$ pyruvate (Gibco), $30 \mathrm{mg} / \mathrm{mL}$ delipidated bovine serum albumin (Millipore Calbiochem, MA USA), $100 \mathrm{U} / \mathrm{mL}$ penicillin and $100 \mathrm{mg} / \mathrm{L}$ streptomycin (Gibco). Adenosine (Sigma-Aldrich) $100 \mathrm{nM}$ was also added to help maintain the integrity of the cells. Dglucose $(7 \mathrm{mM})$ was added as substrate. Each well received $400 \mu \mathrm{L}$ of the adipocyte suspension (a second $100 \mu \mathrm{L}$ aliquot was taken simultaneously to determine the adipocyte content in the well), thus completing a final volume of $2.1 \mathrm{~mL}$. Under these conditions, the cells floated freely (as spheres) and tended to accumulate on the surface of the well. The cells were incubated at 37 ${ }^{\circ} \mathrm{C}$ in an incubation chamber ventilated with air supplemented with $5 \% \mathrm{CO}_{2}$, which gave a theoretical $\mathrm{pO}_{2}$ of $20 \mathrm{kPa}$ (i.e. $0.2 \mathrm{mM}$ of dissolved $\mathrm{O}_{2}$ ) (Romero et al. 2015). The calculated $\mathrm{pCO}_{2}$ was in the range of $5 \mathrm{kPa}$, corresponding to $1.7 \mathrm{mM}$ of dissolved $\mathrm{CO}_{2}$. The cells were incubated for $24 \mathrm{~h}$ or $48 \mathrm{~h}$ without any further intervention. At the end of the experiment, a sample of the well contents was used to determine the number of cells. Then, the cells were harvested and the medium was extracted and frozen.

The incubation medium was used for the estimation of glucose, using a glucose oxidaseperoxidase kit (\#11504, Biosystems, Barcelona Spain) to which we added $740 \mathrm{nkat} / \mathrm{mL}$ mutarrotase (porcine kidney, 136A5000, Calzyme, St Louis, MO USA) (Oliva et al. 2015). Lactate was measured with kit 1001330 (Spinreact, Sant Esteve d'en Bas, Spain), glycerol was 
237 estimated with kit \#F6428 (Sigma-Aldrich); NEFA were measured using kit NEFA-HR(2)

238 (Wako Life Sciences, Mountain View, CA USA).

239 Calculations

240

241

242

243

244

245

246

247

248

249

250

251

252

253

254

255

256

257

258

259

260

261

262

263

264

265

266

267

268

269

A critical factor in the development of this procedure was to keep track of all weights/ volumes and incorporate into the calculations all aliquots extracted for testing (i.e. glucose or lactate levels). All data were introduced in a spreadsheet in which the volumes were justified with a (pipetting) error of $\pm 3 \%$. When possible, or when no other avenue was available, volumes were estimated from differential weights and the application of the densities calculated as described above.

The calculations used to determine the cell parameters, adipocyte recovery and WAT cell distribution are described in the Tables, presenting the original experimental data along with the derived or calculated data, as well as the formulas used for their estimation.

Statistical analyses were carried out using the Prism 5 Program (Graphpad Software Inc., La Jolla, CA USA). Statistical differences between groups of data were determined with the unpaired Student's $t$ test.

\section{Results}

Analysis of the recovery of adipocytes from intact epididymal WAT

Table 1 shows the main experimental data for the quantitative analysis of free isolated adipocyte yield from just-dissected epididymal WAT. Both weight, water and fat content, as expected, showed little variation. The suspension obtained after collagenase digestion was estimated by weight, as were the floating fat layer and the debris retained in the nylon mesh. The number, and mean volume of intact adipocytes was also fairly uniform. The number of free (i.e. unattached to adipocytes) stromal cells was 17-fold higher than that of adipocytes, but almost $3 / 4^{\text {ths }}$ of them were just red blood cells. All stromal cells had cell volumes in the range of $10^{-4}$ of those of adipocytes. The volumes of all stromal cells, including erythrocytes were measured after separation via high-speed centrifugation, which may have altered their original shape and volume, a treatment that the large adipocytes could not endure.

All tables contain a first column, labeled \#, in which a letter and number are given to each row (or datum). These references are later used, in Tables 2 to 6 to present the origin of the data and the calculations done using the experimental data.

Table 2 presents the calculations (largely based on the data in Table 1) used to determine the recovery of viable isolated adipocytes from the intact tissue sample. Since all experimental 
270

271

272

273

274

275

276

277

278

279

280

281

282

283

284

285

286

287

288

289

290

291

292

293

294

295

296

297

298

299

300

301

302

303

304

data referred to weight (its measurement was several-fold more precise than volumetric measurements, especially those implying solids - such as cells - in suspension and mixed-phase systems) the main column of data is that indicated by weights, and have been referred to mg in 1 $\mathrm{g}$ of initial tissue. These values were converted to volumes using the densities experimentally measured for fat and tissue shown in Table 1. The third column shows the origin of the data and the calculations used to obtain the corresponding values.

The detailed calculations of the efficiency of adipocyte recovery can be seen on Tables 1 and 2. We assumed that practically all WAT fat was present in the adipocyte fraction, essentially in adipocytes, since membrane lipids were not extracted with the procedure used (Rose \& Oklander 1965; Remesar et al. 2015), the eventual presence of fat in stromal cells went undetected and, in any case, could not represent a significant amount of material given the combined volume of these cells and their density. Consequently, all the fat present in the final intact adipocyte preparation should correspond to that of adipocytes, since free fat was measured and removed, and there were no other fat-carrying cells in the system in mass and/or numbers sufficient to alter the results, and neither membrane lipids could interfere in a significant way. Our previous work provides additional calculations that further support this conclusion (Remesar et al. 2015). Thus, we could equate the losses of fat (with respect to intact tissue) with losses of adipocytes. These losses were found to be significant, and the manipulation of the cells resulted in additional cells breakup. Under the conditions described, the collagenase incubation and extrusion through the nylon mesh resulted in a loss of about $24 \%$ of the cells (in fact, losses of fat), and the washings of the isolated cells added an additional loss in the range of $3 \%$, which resulted in a recovery of about $73 \%$ of intact functional cells in the final adipocyte preparation, used for incubations, and referred to intact WAT (Table 2).

Isolated adipocyte viability

The viability of the cells obtained was high in the final preparation, with a negligible number of cells broken. The incubation of cells (about 700,000 per well) resulted in a loss of cells of approximately $4 \%$ in the first $24 \mathrm{~h}$ and an additional $9 \%$ in the second $24 \mathrm{~h}$ period. Consequently, the cells were viable and remained functional for 2 additional days in primary culture. The rate of glucose uptake (and metabolic utilization) per cell increased significantly in the second day of incubation. However, the lactate efflux rates were maintained. Glycerol efflux rate also rose several fold in the $24-48 \mathrm{~h}$ period, maintaining, in the end, a much higher efflux rate than that of NEFA, which attests to its mainly glycolytic origin (parallel to the increase in glucose uptake and the maintenance of lactate production). However, the sole presence of NEFA proves that lipolysis was clearly present in the second day, probably as a consequence of the loss of about half of the glucose initially present in the medium (i.e. decreasing its availability to 
305

306

307

308

309

310

311

312

313

314

315

316

317

318

319

320

321

322

323

324

325

326

327

328

329

330

331

332

333

334

335

336

337

338

support cell metabolism). The higher rates of glycerol efflux in comparison with those of NEFA also support the finding that most of glycerol was not of lipolytic origin (Smith 1972; Romero et al. 2015), since then the reverse would be true. In any case, the data prove that metabolic activity (at least glucose uptake, glycolysis to lactate, glycerogenesis and lipolysis) were fully functional in the $48 \mathrm{~h}$ period studied, in fact increasing during the second day of incubation.

\section{Analysis of WAT cell type distribution and proportions, cumulative volumes}

Table 3 shows the calculations derived from the data of Table 1 to obtain an approximate estimation of the combined proportions of tissue volume filled by the three main types of cells we were able to discriminate: adipocytes, nucleated stromal cells and red blood cells. The total mass of adipocytes was scaled up to the tissue volume from the measured data of mean adipocyte volume and its numbers (estimated from tissue and isolated cells' fat content). Adipocytes constituted almost $0.88 \mathrm{~mL} / \mathrm{g}$ WAT volume. Total stromal cells and erythrocytes' volumes were, likewise, calculated from their mean cell size and numbers, scaled up to the volume of $1 \mathrm{~g}$ of intact WAT. Despite their larger numbers, the combined total volume of all stromal cells accounted for a little more than $2 \mu \mathrm{L} / \mathrm{g}$ WAT.

Using the adipocyte fat content and its volume (both referred to $1 \mathrm{~g}$ of tissue weight minus debris), as shown in Table 4, we obtained an approximate estimation of the "live cell mas" of adipocytes in epididymal WAT. This volume included all the cell organelles, systems and cytoplasm, since the fat vacuole volume corresponds to the fat content, estimated from tissue mass and its direct measurement of fat content. The total cell volume, only slightly larger, was calculated from another set of data: cell counting and mean volumes, tracing the cell losses from those of fat. The small difference between both entities was in the range of $1,5 \%$ of the cell volume, and taken as such, despite the wide margin of error and the small number of animals used to calculate this mean value, it represents a very small proportion of the whole tissue, which magnifies its active metabolic performance.

Table 5 shows the global distribution of epididymal WAT volume and the space taken up by the three types of cells analyzed. Adipocytes took up $90 \%$ of the tissue volume (excluding the "debris", largely vessels and other structures or undigested tissue), but their number was only $7 \%$ of the total number of cells. Nucleated stromal cells hardly took $0.2 \%$ of the volume but accounted for $27 \%$ of the cells. Red blood cells were the most abundant, $66 \%$ of numbers, but their space was only $0.05 \%$, a value that roughly corresponds to $1 \mu \mathrm{L}$ of whole blood per $g$ of WAT (the rats were exsanguinated, thus this is a residual tissue blood volume). Cells did not occupy all the tissue space, since about $10 \%$ of the tissue volume was extracellular space (interstitial and vascular). Fat alone filled $89 \%$ of the tissue space. 
Table 6 summarizes the mean characteristics of the adipocytes extracted from rat epididymal WAT. Their estimated non-fat cell volume was in the range of $13 \mathrm{pL}$, much larger than the $273 \mathrm{fL}$ of nucleated stromal cells and the $26 \mathrm{fL}$ of red blood cells (Table 1). Adipocytes' "live cell volume" was 48x higher than nucleated stromal or 500x higher than red blood cells. But their complete volume (i.e. including the single fat vacuole) was, respectively, 1,700x and 18,000x larger. The combined non-fat adipocyte volume was (Table 5) about one order of magnitude higher than that of nucleated stromal cells. Thus, despite their lower numbers, the mass of "live-cell material" of adipocytes remains the main active component of WAT at least using these gross comparison tools.

\section{Discussion}

Probably, the most striking conclusion of the present study is the very small proportion of "live cell matter" found in epididymal WAT of normal young adult rats. Fat stores take up an inordinate amount of the tissue space, the interstitial space found is close to that described in previous reports and is in the range of other tissues (Robert \& Alemany 1981). However, after excluding the inert fat deposits, the remaining "cell material" accounts for about $1.5 \%$ of the total tissue mass, which seems very little even in relation to the assumedly limited metabolic activity of the tissue.

The data and viability of cells obtained with our customized version of the Rodbell (Rodbell 1964) method for isolation of adipocytes reflect a specific experimental condition, and their absolute values are obviously subjected to a number of possible modifying conditions, such as small changes in the conditions of extraction, the length of incubation, the inflammatory condition of WAT, the location of WAT depots, and the age, mass of WAT and sex of the animals used. Primary adipocytes may be incubated for long periods without loss of response to hormonal or paracrine stimuli (Marshall et al. 1984; Fain \& Madan 2005; Giovambattista et al. 2006). The lineal response to excess medium glucose producing lactate for up to $48 \mathrm{~h}$ is comparable to that described previously by us in 3T3L1 cells (Sabater et al. 2014). The increased secretion of glycerol and NEFA during the second day of incubation attest not to a loss of metabolic response and viability but to a change in the mechanisms of control of substrate efflux (unpublished results) in agreement with the known glycerogenesis from glucose and limited lipolysis of adipocytes exposed to glucose (Romero et al 2015).

It is well known that adipose tissue presents considerable difficulties to work with, the main problem being the dilution of cell proteins, RNA and DNA, as well as its wide variation in almost any parameter, largely attributed to the space occupied by huge fat stores. Evidently, this is not new, but the actual quantification, albeit approximate, of this entity is. The results may 
374

375

376

377

378

379

380

381

382

383

384

385

386

387

388

389

390

391

392

393

394

395

396

397

398

399

400

401

402

403

404

405

406

407

408

409

seem perhaps extreme, but the combined volume of fat (we often measure the weight, not the volume of fat depots) and extracellular space (i.e. plasma, and interstitial space) markedly limit the possible volume of the sum of blood cells, nucleated stromal cells and adipocyte non-fat cell volume. These considerations support, at least the range of "live cell" volume we have presented here for WAT. It is obvious that the data calculated from the actual experimental results is only an approximation to the real values of this "live-cell" volume of adipose tissue cells. However, the data involved: percentage of fat in the intact tissue, and the combination of mean cell volume and number of adipocytes yield very close figures, with a small difference in cell size over vacuolar fat size. The different origin of the data, plus the use of different animals to get the means (the individual variability gave too much dispersion), decided us to work with experimentally-derived mean values to diminish the noise or clutter of individual data on the calculated/ derived parameters. In previous works, we have proven the remarkable metabolic activity of the sum of WAT depots (i.e. taken as adipose organ) (Arriarán et al. 2015b; Arriarán et al. 2015c), especially its considerable glycolytic capability (under normoxic conditions) (Arriarán et al. 2015c; Romero et al. 2015), which adds to its known ability to store fatty acids taken from plasma lipoproteins (Garfinkel et al. 1967; Wang et al. 2016) or synthesized from glucose (Guerre-Millo 2003). Its important contribution to amino acid metabolism (Arriarán et al. 2015a), second only to liver (Agnelli et al. 2016; Arriarán et al. 2016), supports the longproposed active WAT implication in energy and intermediate / substrate metabolism (Cahill 1962). The data presented here only compound the puzzle, since the actual mass of cells doing the work is only a small fraction of the tissue, much lower than usually assumed. This small number of cells (including the stromal nucleated cells) is able to produce a large number of signaling cytokines (Gerner et al. 2013; Wisse 2004), hormones (Killinger et al. 1995; Stimson et al. 2009) and maintain an active capacity to defend (immune system) (Chmelar et al. 2013), and repair or regenerate (i.e. stem cells) (Ogura et al. 2014) tissues. Compared to liver, which cell volume is upwards of $75 \%$ of its volume, the 50-fold lower proportion of WAT "live cell" volume has to show a much higher metabolic activity to be able to carry out the large number of functions and active metabolism that we keep discovering in recent times in WAT. The actual quantitation of the mass of adipocyte cytosol and its correlation with metabolic activity is a study worth carrying out, to definitively establish that WAT cells metabolism is extremely active, and not a dump for excess energy.

Surprisingly, the most abundant cells found in WAT were red blood cells, which accounted for roughly two thirds of the total. The volume of red blood cells was the approximate equivalent to about $1 \mu \mathrm{L}$ of blood per g WAT, lower than previously published data using ${ }^{65} \mathrm{Fe}-$ labelled red blood cells (Robert \& Alemany 1981). Probably, the blood figure will be higher in vivo, since the rats were killed by exsanguination, so that most of the blood was drained. 
410 Consequently, we can assume that in vivo, WAT blood content may justify a hefty proportion of 411 the tissue cells.

412 For operative methodological simplicity, we have analyzed all non-adipocyte cells 413 ("stromal") as a single entity, but we have considered apart, independently, red blood cells, first 414 for their relatively large proportion, and second because of their limited metabolic activity (and 415 absence of nuclei). Nevertheless, the combined volume of the nucleated stromal cells was, again, 416 smaller than expected. We are reasonably certain that the methodology used accounted for all 417 free tissue cells in this fraction, since only low-density cells (i.e. adipocytes, and -probably418 differentiating preadipocytes) (Grégoire et al. 1990) were separated by the low centrifugation 419 force used. Our stromal cell data are difficult to compare with the large number of studies 420 available that analyze WAT cell populations under different metabolic conditions, since in 421 practically all cases, the studies are not quantitative, neither referred to initial tissue mass, and 422 are usually centered on preadipocytes (Grégoire et al. 1990), macrophages (Makkonen et al. 423 2007), vascular (Kajimoto et al. 2010) or other specific cell types (Villaret et al. 2010). In 424 addition, most data on WAT adipocyte counts were done in fixed and stained WAT histologic 425 cuts, where, usually, only section areas (of adipocytes) are taken into account, irrespective of the 426 level of the cell at which they have been sliced and then estimated.

427

The ever present problem of lipid droplets in cell suspensions has been partially solved in this case by letting them coalesce in a lipid layer before counting adipocytes in microphotographs. Nuclear staining may open new possibilities for counting, but the probable presence of other cells attached to adipocytes (i.e. not removed by the washings) and the need to maintain the integrity of the cells for sizing has prevented the use of this approach in the present study.

We expected to find larger numbers of stromal cells, obviously more than blood cells, because this relatively small part of the tissue is responsible for a large number of its metabolic functions and control responses as explained above, and is subjected to considerable variability related to its location and to inflammation (Cildir et al. 2013; Villaret et al. 2010). In any case, adipocytes remain by large (percentage of WAT volume either counting the fat vacuoles or not) the main component of WAT cell populations, but this primacy was lost when considering the numbers of cells.

One of the critical points this study tried to address was the efficiency of viable cell isolation from freshly dissected WAT and the maintenance of their functions for up to two days of incubation. The cell separation method we used is standard, and so widely used that seldom the source is cited, ensuring a fair recovery of the delicate adipocytes with minimal losses. We 444 quantified these losses, and found that the recovery was initially close to $76 \%$ of the cells 
445 initially present in the tissue; but incubation resulted in the additional loss of significant (albeit

446 relatively small) numbers of cells. In any case, we presented a method that allows the 447 establishment of a quantitative relationship between the numbers of functional cells obtained 448 with respect to the initial tissue mass, in the range of $73 \%$. The data refer to viable cells, able to 449 take up glucose from the medium, glycolyse it to produce lactate, and synthesize glycerol, part of 450 which (as attested by the production of NEFA) was the product of lipolysis. In fact, the data 451 presented show a marked increase in the efflux of glycerol and NEFA during the second day of 452 incubation, at the expense of higher glucose uptake, proof that the cells were not losing 453 functionality during the $24-48 \mathrm{~h}$ incubation, but increasing their utilization of glucose, which was

454

455

456

457

458

459

460

461

462

463

464

465

466

467

468

469

470

471

472

473

474

475

476

477

478

479 comparable to that of 3T3L1 adipocytes (Sabater et al. 2014). The maintenance of function of adipocytes obtained with the Rodbell method (Rodbell 1964), as is our case, has been repeatedly tested for periods of two days (or longer) in a wide variety of metabolic pathways and response to hormonal or chemical stimuli (Marshall et al. 1983; Fain \& Madan 2005; Giovambattista et al. 2006). However, the analysis of recovery was based essentially on the analysis of lipid in all fractions, so that the measurement of volumes (or weights) was critical and introduced a number of factors to be considered for success. First, all cells floating in the buffer after treatment with collagenase and separation of debris (i.e. low density, and preferentially of large volume), were considered adipocytes. Just leaving the cells standing (i.e. centrifugation at $1 \mathrm{xg}$ ) 5 min prevented pressure-caking of adipocytes and their breakage, but allowed a uniform distribution of smaller stromal cells between both phases. This was no problem for their estimation (numbers and volumes), but introduced a possible source of error when using isolated adipocytes for metabolic analysis, since the nucleated stromal cells remained a significant fraction of the crude adipocyte suspension. Three washings resulted in the loss of about $3 \%$ of adipocytes, but theoretically removed almost all non-attached stromal cells, down to a negligible proportion of the initial stromal cells content in the adipocyte fraction. The numbers and volumes of adipocytes found were in the range of those described in the literature (DiGirolamo \& Owens 1976; Francendese \& Digirolamo 1981). In addition, the cell volumes estimated, combined with the numbers of cells measured accounted for almost all the tissue space available, which is, in itself, an internal check that our calculations and estimations were essentially correct.

\section{Conclusions}

The methodology presented here for the estimation of adipocyte recovery allows for a direct quantitative reference to the original intact tissue of studies with isolated cells. This way, the cultured cell data can be used as an approximation to metabolic activity and function related to whole organism. 
480

481

482

483

484

485

486

487

488

489

490

491

492

493

494

495

496

497

498

499

500

501

502

503

504

505

506

507

We have presented proof that the "live cell mass" of adipose tissue is very small. This fact, translates into an extremely high (with respect to the actual "live cytoplasm" size) metabolic activity to justify the overall activity of WAT in glucose-fatty acid relationships, but also in amino acid metabolism. These data justify that comparison of epididymal WAT, often considered the less metabolically active part of the adipose organ, with more metabolically relevant tissues such as liver should take into account these quantitative data, which make WAT an even more significant agent in the control of energy metabolism.

\section{Acknowledgements}

Thanks are given to Dr. Marta Camps for her help with practical aspects cell isolation methodology. We also thank the staff of the Scientific and Technological Services of the University of Barcelona for their help in the use of cell technologies.

\section{References}

Agnelli S, Arriarán S, Oliva L, Remesar X, Fernández-Lápez J-A, and Alemany M. 2016. Modulation of rat liver urea cycle and related ammonium metabolism by sex and cafeteria diet. RSC Advances 6:11278-11288.

Alemany M, and Fernández-López JA. 2006. Adipose tissue: something more than just adipocytes. Current Nutrition and Food Science 2:141-150.

Alkhouli N, Mansfield J, Green E, Bell J, Knight B, Liversedge N, Tham JC, Welbourn R, Shore AC, Kos K, and Winlove CP. 2013. The mechanical properties of human adipose tissues and their relationships to the structure and composition of the extracellular matrix. American Journal of Physiology 305:E1427-E1435.

Arriarán S, Agnelli S, Remesar X, Alemany M, and Fernández-López JA. 2016. White adipose tissue urea cycle activity is not affected by one-month treatment with a hyperlipidic diet in female rats. Food and Function 7:1554-1563.

Arriarán S, Agnelli S, Remesar X, Fernández-López J-A, and Alemany M. 2015a. The urea cycle of rat white adipose tissue. RSC Advances 5:93403-93414. 
508 509 510

Arriarán S, Agnelli S, Remesar X, Fernández-López JA, and Alemany M. 2015b. Effects of sex and site on amino acid metabolism enzyme gene expression and activity in rat white adipose tissue. PeerJ 3:e1399.

Arriarán S, Agnelli S, Sabater D, Remesar X, Fernández-López JA, and Alemany M. 2015c. Evidences of basal lactate production in the main white adipose tissue sites of rats. Effects of sex and a cafeteria diet. PloS One 10:e0119572.

Baviskar SN. 2011. A quick \& automated method for measuring cell area using ImageJ. American Biology Teacher 73:554-556.

Cahill GF. 1962. Metabolic role of adipose tissue. Transactions of the American Clinical and Climatologic Association 73:22-29.

Chmelar J, Chung KJ, and Chavakis T. 2013. The role of innate immune cells in obese adipose tissue inflammation and development of insulin resistance. Thrombosis and Haemostasis 109:399-406.

Choe SS, Huh JY, Hwang IJ, Kim JI, and Kim JB. 2016. Adipose tissue remodeling: Its role in energy metabolism and metabolic disorders. Frontiers in Endocrinology 7:30.

Cignarelli A, Perrini S, Ficarella R, Peschechera A, Nigro P, and Giorgino F. 2012. Human adipose tissue stem cells: relevance in the pathophysiology of obesity and metabolic diseases and therapeutic applications. Expert Reviews in Molecular Medicine 14:e19.

Cildir G, Akincilar SC, and Tergaonkar V. 2013. Chronic adipose tissue inflammation: all immune cells on the stage. Trends in Molecular Medicine 19:487-500.

Cinti S. 2001. The adipose organ: morphological perspectives of adipose tissues. Proceedings of the Nutrition Society 60:319-328.

da Silva Meirelles L, Maistro Malta T, Wagatsuma VMD, Viana Bonini Palma P, Goes Araújo A, Ribeiro Malmegrim KC, Morato de Oliveira F, Alexandre Panepucci R, Araújo Silva W, Kashima Haddad S, and Tadeu Covas D. 2015. Cultured human adipose tissue pericytes and mesenchymal stromal cells display a very similar gene expression profile. Stem Cells and Development 24:2822-2840. 
535 Deschênes D, Couture P, Dupont P, and Tchernof A. 2003. Subdivision of the subcutaneous

536

537

538

539

540

541

542

543

544

545

546

547

548

549

550

551

552

553

554

555

556

557

558

559

560

561 adipose tissue compartment and lipid-lipoprotein levels in women. Obesity Research 11:469-476.

DiGirolamo M, and Owens JL. 1976. Water content of rat adipose tissue and isolated adipocytes in relation to cell size. American Journal of Physiology 231:1568-1572.

Dixit VD. 2008. Adipose-immune interactions during obesity and caloric restriction: reciprocal mechanisms regulating immunity and health span. Journal of Leukocyte Biology 84:882892.

Domergue S, Bony C, Maumus M, Toupet K, Frouin E, Rigau V, Vozenin MC, Magalon G, Jorgensen C, and Noel D. 2016. Comparison between stromal vascular fraction and adipose mesenchymal stem cells in remodeling hypertrophic scars. PloS One 11: e0156161.

Eder K, Reichlmayr-Lais AM, and Kirchgeßner M. 1993. Studies on the extraction of phospholipids from erythrocyte membranes in the rat. Clinica Chimica Acta 219:93-104.

Fain JN \& Madan AK 2005 Insulin enhances vascular endothelial growth factor, interleukin-8, and plasminogen activator inhibitor 1 but not interleukin- 6 release by human adipocytes. Metabolism Clinical and Experimental 54 220-226.

Folch J, Lees M, and Sloane-Stanley GH. 1957. A simple method for the isolation and purification of total lipides from animal tissues. Journal of Biological Chemistry 226:497-509.

Francendese AA, and Digirolamo M. 1981. Alternative substrates for triacylglycerol synthesis in isolated adipocytes of different size from the rat. Biochemical Journal 194:377-384.

Garfinkel A, Baker N, and Schotz MC. 1967. Relationship of lipoprotein lipase activity to triglyceride uptake in adipose tissue. Journal of Lipid Research 8:274-280.

Garvey WT, Olefsky JM, Matthaei S, and Marshall S. 1987. Glucose and insulin co-regulate the glucose transport system in primary cultured adipocytes. A new mechanism of insulin resistance. Journal of Biological Chemistry 262:189-197. 
562 Gerner RR, Wieser V, Moschen AR, and Tilg H. 2013. Metabolic inflammation: role of

563

564

565

566

567

568

569

570

571

572

573

574

575

576

577

578

579

580

581

582

583

584

585

586

587

588

589

590 cytokines in the crosstalk between adipose tissue and liver. Canadian Journal of Physiology and Pharmacology 91:867-872.

Giovambattista A, Piermaría J, Suescun MO, Calandra RS, Gaillard RC \& Spinedi E 2006 Direct effect of ghrelin on leptin production by cultured rat white adipocytes. Obesity 14 19-27.

Gimble JM, Bunnell BA, Chiu ES, and Guilak F. 2011. Concise review: Adipose-derived stromal vascular fraction cells and stem cells: Let's not get lost in translation. Stem Cells 29:749-754.

Grégoire F, Todoroff G, Hauser N, and Remacle C. 1990. The stroma-vascular fraction of rat inguinal and epididymal adipose tissue and the adipoconversion of fat cell precursors in primary culture. Biology of the Cell 69:215-222.

Guerre-Millo M. 2003. Extending the glucose/fatty acid cycle: a glucose/adipose tissue cycle. Biochemical Society Transactions 31:1161-1164.

Hall J, Roberts R, and Vora N. 2009. Energy homeostasis: the roles of adipose tissue-derived hormones, peptide YY and ghrelin. Obesity Facts 2:117-125.

Hill AA, Bolus WR, and Hasty AH. 2014. A decade of progress in adipose tissue macrophage biology. Immunological Reviews 262:134-152.

Honnor RC, Dhillon GS, and Londos C. 1985. cAMP-dependent protein-kinase and lipolysis in rat adipocytes .1. Cell preparation, manipulation, and predictability in behavior. Journal of Biological Chemistry 260:15122-15129.

Kajimoto K, Hossen MN, Hida K, Ohga N, Akita H, Hyodo M, Hida Y, and Harashima H. 2010. Isolation and culture of microvascular endothelial cells from murine inguinal and epididymal adipose tissues. Journal of Immunological Methods 357:43-50.

Killinger DW, Strutt BJ, Roncari DA, and Khalil MW. 1995. Estrone formation from dehydroepiandrosterone in cultured human breast adipose stromal cells. Journal of Steroid Biochemistry and Molecular Biology 52:195-201.

Kotronen A, Seppänen-Laakso T, Westerbacka J, Kiviluoto T, Arola J, Ruskeepää AL, YkiJarvinen H, and Oresic M. 2010. Comparison of lipid and fatty acid composition of the liver, subcutaneous and intra-abdominal adipose tissue, and serum. Obesity 18:937-944. 
591

592

593

594

595

596

597

598

599

600

601

602

603

604

605

606

607

608

609

610

611

612

613

614

615

616

617

618

Lee J. 2013. Adipose tissue macrophages in the development of obesity-induced inflammation, insulin resistance and type 2 Diabetes. Archives of Pharmacal Research 36:208-222.

Leonhardt W, Hanefeld M, and Haller H. 1978. The adipocyte volume in human adipose tissue: 1.Lipid space, normal and maximum values, and the relation to body weight index. International Journal of Obesity 2:33-45.

Li QK, Hata A, Kosugi C, Kataoka N, and Funaki M. 2010. The density of extracellular matrix proteins regulates inflammation and insulin signaling in adipocytes. FEBS Letters 584:4145-4150.

Liu YJ, Aron-Wisnewsky J, Marcelin G, Genser L, Le Naour G, Torcivia A, Bauvois B, Bouchet S, Pelloux V, Sasso M, Miette V, Tordjman J, and Clement K. 2016. Accumulation and changes in composition of collagens in subcutaneous adipose tissue after bariatric surgery. Journal of Clinical Endocrinology and Metabolism 101:293-304.

Lolmède K, Duffaut C, Zakaroff-Girard A, and Bouloumie A. 2011. Immune cells in adipose tissue: Key players in metabolic disorders. Diabetes and Metabolism 37:283-290.

Luche E, Sengenès C, Arnaud E, Laharrague P, Casteilla L, and Cousin B. 2015. Differential hematopoietic activity in white adipose tissue depending on its localization. Journal of Cellular Physiology 230:3076-3083.

Makkonen J, Westerbacka J, Kolak M, Sutinen J, Corner A, Hamsten A, Fisher RM, and YkiJarvinen H. 2007. Increased expression of the macrophage markers and of 11b-HSD-1 in subcutaneous adipose tissue, but not in cultured monocyte-derived macrophages, is associated with liver fat in human obesity. International Journal of Obesity 31:16171625.

Marshall S, Garvey WT \& Miriam G 1984 Primary culture of isolated adipocytes. A new model to study insulin receptor regulation and insulin action. Journal of Biological Chemistry $2596375-6384$.

Mitterberger MC, Lechner S, Mattesich M, and Zwerschke W. 2014. Adipogenic differentiation is impaired in replicative senescent human subcutaneous adipose-derived stromal/progenitor cells. Journals of Gerontology 69A:13-24. 
619 Mjös OD, and Akre S. 1971. Effect of chatecolamines on blood flow, oxygen consumption, and 620 release/uptake of free fatty acids in adipose tissue. Scandinavian Journal of Clinical and $621 \quad$ Laboratory Investigation 27:221-225.

622 Nawrocki AR, and Scherer PE. 2005. The adipocyte as a drug discovery target. Drug Discovery 623 Today 10:1219-1230.

624 O'Brien SN, Mantzke KA, Kilgore MW, and Price TM. 1996. Relationship between adipose 625 stromal-vascular cells and adipocytes in human adipose tissue. Analytical and $626 \quad$ Quantitative Cytology and Histology 18:137-143.

627 Ogura F, Wakao S, Kuroda Y, Tsuchiyama K, Bagheri M, Heneidi S, Chazenbalk G, Aiba S, and 628 629 Dezawa M. 2014. Human adipose tissue possesses a unique population of pluripotent stem cells with nontumorigenic and low telomerase activities: potential implications in regenerative medicine. Stem Cells and Development 23:717-728.

Oishi Y, and Manabe I. 2016. Integrated regulation of the cellular metabolism and function of immune cells in adipose tissue. Clinical and Experimental Pharmacology and Physiology 43:294-303.

634

635

Oliva L, Baron C, Fernández-López J-A, Remesar X, and Alemany M. 2015. Marked increase in rat red blood cell membrane protein glycosylation by one-month treatment with a cafeteria diet. PeerJ 3:e1101.

Parker AM, and Katz AJ. 2006. Adipose-derived stem cells for the regeneration of damaged 638 tissues. Expert Opinion on Biological Therapy 6:567-578.

Pasarica M, Sereda OR, Redman LM, Albarado DC, Hymel DT, Roan LE, Rood JC, Burk DH, and Smith SR. 2009. Reduced adipose tissue oxygenation in human obesity-Evidence for rarefaction, macrophage chemotaxis, and inflammation without and angiogenic response. Diabetes 58:718-725.

Robert M, and Alemany M. 1981. Water compartments in the tissues of pentobarbital anesthetized rats. IRCS Medical Science 9:236-237.

Rodbell M. 1964. Metabolism of isolated fat cells. I. Effects of hormones on glucose metabolism 646 and lipolysis. Journal of Biological Chemistry 239:375-380. 
647 Romero MM, Sabater D, Fernández-López JA, Remesar X, and Alemany M. 2015. Glycerol 648 production from glucose and fructose by 3T3-L1 cells: A mechanism of adipocyte 649 defense from excess substrate. PloS One 10:e139502.

650 Rose H, and Oklander M. 1965. Improved procedure for the extraction of lipids from human 651 erythrocytes. Journal of Lipid Research 6:428-431.

652

653

654

655

656

657

658

659

660

661

662

663

664

665

666

667

668

669

670

671

672

673

674

Remesar X, Antelo A, Llivina C, Albà E, Berdié L, Agnelli S, Arriarán S, Fernández-López JA \& Alemany M 2015 Influence of a hyperlipidic diet on the composition of the nonmembrane lipid pool of red blood cells of male and female rats. PeerJ 3: e1083Sabater D, Arriarán S, Romero MM, Agnelli S, Remesar X, Fernández-López JA, and Alemany M. 2014. Cultured 3T3L1 adipocytes dispose of excess medium glucose as lactate under abundant oxygen availability. Scientific Reports 4:3663.

Sadie van Gijsen H, Smith W, du Toit EF, Michie J, Hough FS, and Ferris WF. 2012. Depotspecific and hypercaloric diet-induced effects on the osteoblast and adipocyte differentiation potential of adipose-derived stromal cells. Molecular and Cellular Endocrinology 348:55-66.

Sell H, and Eckel J. 2010. Adipose tissue inflammation: novel insight into the role of macrophages and lymphocytes. Current Opinion in Clinical Nutrition and Metabolic Care 13:366-370.

Smith U. 1972. Studies of human adipose tissue in culture. I. Incorporation of glucose and release of glycerol. Anatomical Record 172:597-602.

Stimson RH, Andersson J, Andrew R, Redhead DN, Karpe F, Hayes PC, Olsson T, and Walker BR. 2009. Cortisol release from adipose tissue by 11b-Hydroxysteroid Dehydrogenase type 1 in humans. Diabetes 58:46-53.

Sumi M, Sata M, Toya N, Yanaga K, Ohki T, and Nagai R. 2007. Transplantation of adipose stromal cells, but not mature adipocytes, augments ischemia-induced angiogenesis. Life Sciences 80:559-565.

Takahara K, Ii M, Inamoto T, Komura K, Ibuki N, Minami K, Uehara H, Hirano H, Nomi H, Kiyama S, Asahi M, and Azuma H. 2014. Adipose-derived stromal cells inhibit prostate 
675

676

677

678

679

680

681

682

683

684

685

686

687

688

689

690

691

692

693

694

695

696

697

698

cancer cell proliferation inducing apoptosis. Biochemical and Biophysical Research Communications 446:1102-1107.

Thompson ACS, Nuñez M, Davidson R, Horm T, Schnittker K, Hart MV, Suarez AM, and Tsao TS. 2012. Mitigation of isolation-associated adipocyte interleukin-6 secretion following rapid dissociation of adipose tissue. Journal of Lipid Research 53:2797-2805.

Tordjman K, Leingang K, and Mueckler M. 1990. Differential regulation of the HepG2 and adipocyte/muscle glucose transporters in 3T3L1 adipocytes. Effect of chronic glucose deprivation. Biochemical Journal 271:201-207.

Vielma SA, Klein RL, Levingston CA, and Young MRI. 2013. Adipocytes as immune regulatory cells. International Immunopharmacology 16:224-231.

Villaret A, Galitzky J, Decaunes P, Esteve D, Marques MA, Sengenes C, Chiotasso P, Tchkonia T, Lafontan M, Kirkland JL, and Bouloumie A. 2010. Adipose tissue endothelial cells from obese human subjects: differences among depots in angiogenic, metabolic, and inflammatory gene expression and cellular senescence. Diabetes 59:2755-2763.

Wang MY, Gao MM, Liao JW, Qi YF, Du XM, Wang YH, Li L, Liu G, and Yang HY. 2016. Adipose tissue deficiency results in severe hyperlipidemia and atherosclerosis in the lowdensity lipoprotein receptor knockout mice. Biochimica et Biophysica Acta 1861:410418.

Wisse BE. 2004. The inflammatory syndrome: The role of adipose tissue cytokines in metabolic disorders linked to obesity. Journal of the American Society of Nephrology 15:27922800 .

Wronska A, and Kmiec Z. 2012. Structural and biochemical characteristics of various white adipose tissue depots. Acta Physiologica 205:194-208. 


\section{Table $\mathbf{1}$ (on next page)}

Results obtained from the collagenase digestion of rat epididymal WAT and the analysis of the tissue and fractions of tissue obtained in the process of separation of viable isolated adipocytes

The data presented as mean \pm sd are direct experimental results obtained from four different rats. 
\# parameter

A1 epididymal WAT weight

A2 WAT fat content

A3 WAT water content

A4 adipocyte suspension (digested tissue)

A5 floating fat derived from broken adipocytes

A6 intact adipocytes suspension (A4 - A5)

A7 fat in the intact adipocytes suspension

A8 total fat in the intact adipocytes suspension

A9 water in the intact adipocytes suspension

A10 recovery of intact adipocytes

A11 adipocyte mean volume

A12 extraction debris mass (dry weight)

A13 number of total stromal cells freed

A14 stromal cells' mean volume

A15 red blood cells (proportion of A13, total stromal cells)

A16 red blood cells' mean volume

$\mathrm{dt}$ intact WAT density

dl WAT fat density

$\begin{array}{cc}\text { units } & \text { values } \\ \mathrm{g} & 4.32 \pm 0.44 \\ \mathrm{mg} / \mathrm{g} & 869 \pm 15 \\ \mathrm{mg} / \mathrm{g} & 45 \pm 6 \\ \mathrm{~g} & 4.78 \pm 0.86 \\ \mathrm{mg} & 105 \pm 96 \\ \mathrm{~g} & 4.67 \pm 0.85 \\ \mathrm{mg} / \mathrm{g} & 537 \pm 199 \\ \mathrm{~g} & 2.51 \pm 1.06 \\ \mathrm{mg} / \mathrm{g} & 287 \pm 68 \\ \mathrm{cells} \mathrm{x} 10^{6} & 5.82 \pm 3.06 \\ \mathrm{pL} & 475 \pm 147 \\ \mathrm{mg} & 356 \pm 13 \\ \mathrm{cells} \mathrm{x} \mathrm{10} & 103 \pm 45 \\ \mathrm{fL} & 96.6 \pm 43.0 \\ \text { \% } & 71.4 \pm 8.5 \\ \mathrm{fL} & 25.9 \pm 1.1 \\ \mathrm{~g} / \mathrm{mL} & 0.940 \pm 0.013 \\ \mathrm{~g} / \mathrm{mL} & 0,922 \pm 0.022\end{array}$




\section{Table 2 (on next page)}

Analysis of the effectivity of the adipocyte isolation procedure used based on the analysis of lipid distribution, from intact tissue to the final preparation of adipocytes

The data are mean values calculated from the experimental data in Table 1. The column "calculations" explains the data used in each case.

Volumes were calculated with $\mathrm{dt}$ or $\mathrm{dl}$ (Table 1 ) when applied to tissue $(\mathrm{V}=\mathrm{W} / \mathrm{dt})$ or lipid $(\mathrm{V}=\mathrm{W} / \mathrm{dl})$, where $\mathrm{W}$ is weight (in $\mathrm{g}$ ) and $\mathrm{V}$ volume (in $\mathrm{mL}$ ). In the calculations marked ( $\mathrm{W}$ and $\mathrm{V}$ ), the values were calculated directly from weights and volumes, i.e. not applying the density factors. 
\# parameter

B1 intact epididymal WAT

B2 extraction debris (dry weight)

B3 WAT fat content

B4 WAT mass minus debris

B5 WAT fat content corrected by debris

B6 lipid, from broken adipocytes, in the fat layer

B7 total WAT fat in the extracted adipocytes

B8 total fat in the intact adipocytes recovered

B9 total fat in the adipocytes recovered (intact or broken)

B10 fat loss during adipocyte isolation

B11 percentage of adipocyte fat recovery

B12 percentage of adipocytes (fat) lost in the fat layer

B13 percentage of intact adipocytes

$\begin{array}{ccl}\begin{array}{c}\text { weight } \\ \text { mg/g intact }\end{array} & \begin{array}{c}\text { volume } \\ \mu \text { L } / \text { intact }\end{array} & \text { calculations } \\ \text { WAT } & \text { WAT } & \\ 1000 & 1064 & \\ 83 & 88 & (\mathrm{~A} 12 \times \mathrm{B} 1) / \mathrm{A} 1 \\ 869 \pm 15 & 943 & \mathrm{~A} 2 \\ 917 & 976 & \mathrm{~B} 1-\mathrm{B} 2(\mathrm{~W} \text { and } \mathrm{V}) \\ 797 & 865 & (\mathrm{~B} 3 \times \mathrm{B} 4) / \mathrm{B} 1(\mathrm{~W} \text { and } \mathrm{V}) \\ 24 & 26 & (\mathrm{~A} 5 \times \mathrm{B} 1) / \mathrm{A} 1 \\ 773 & 838 & \mathrm{~B} 5-\mathrm{B} 6(\mathrm{~W} \text { and } \mathrm{V}) \\ 581 & 630 & (\mathrm{~A} 8 \times \mathrm{B} 1) / \mathrm{A} 1 \\ 605 & 657 & \mathrm{~B} 6+\mathrm{B} 8(\mathrm{~W} \text { and } \mathrm{V}) \\ 192 & 208 & \mathrm{~B} 5-\mathrm{B} 9(\mathrm{~W} \text { and } \mathrm{V}) \\ 75.9 & -- & (\mathrm{B} 9 / \mathrm{B} 5) \times 100 \\ 3.1 & -- & (\mathrm{B} 6 / \mathrm{B} 5) \times 100 \\ 72.8 & -- & (\mathrm{B} 8 / \mathrm{B} 5) \times 100 \\ & & \end{array}$




\section{Table 3(on next page)}

Calculation of the volumes of cells from rat epididymal WAT

Data calculated using the experimental results presented in Tables 1 and 2. 
\# parameter

$\mathrm{C} 1$ adipocytes in WAT

C2 combined volume of WAT adipocytes

C3 stromal cells in WAT

$\mathrm{C} 4$ red blood cells in WAT

C5 nucleated stromal cells in WAT

C6 total volume of stromal cells in WAT

C7 total volume of red blood cells in WAT

C8 total volume of nucleated stromal cells in WAT

C9 mean nucleated stromal cell volume

$$
\text { ce }
$$

units
cells x 106/g WAT
$\mu \mathrm{L} / \mathrm{g} \mathrm{WAT}$
cells x $10^{6} / \mathrm{g} \mathrm{WAT}$
cells $\times 10^{6} / \mathrm{g}$ WAT
cells $\times 10^{6} / \mathrm{g}$ WAT
$\mu \mathrm{L} / \mathrm{g} \mathrm{WAT}$
$\mu \mathrm{L} / \mathrm{g} \mathrm{WAT}$
$\mu \mathrm{L} / \mathrm{g} \mathrm{WAT}$
$\mathrm{fL}$

values calculations

1.85 (B5 / B1) x (A10 / A8)

$878 \quad(\mathrm{~A} 11 \times \mathrm{C} 1) / 10^{6}$

$23.9 \mathrm{~A} 13 / \mathrm{A} 1$

$17.0 \quad(\mathrm{C} 3 \times \mathrm{A} 15) / 100$

$6.8 \mathrm{C} 3-\mathrm{C} 4$

$2.3 \quad(\mathrm{C} 3 \times \mathrm{A} 14) / 10^{9}$

$0.44(\mathrm{C} 4 \times \mathrm{A} 16) / 10^{9}$

$1.87 \quad \mathrm{C} 6-\mathrm{C} 7$

$273 \quad(\mathrm{C} 8 / \mathrm{C} 5) \times 10^{9}$ 


\section{Table 4 (on next page)}

Calculation of the non-fat cell volume of adipocytes in rat epididymal WAT

Data calculated using the experimental data presented in Tables 1-3. 
\# parameter

D1 total volume of adipocytes in $1 \mathrm{~g}$ of WAT

D2 total fat volume in $1 \mathrm{~g}$ of WAT

D3 non-fat adipocyte cell volume in $1 \mathrm{~g}$ of WAT volume $(\mu \mathrm{L} / \mathrm{g} \quad \%$ of total cells WAT)

878

865

13 volume

100

98,5

1.5

D1 - D2 
Table 5 (on next page)

Distribution of cell types by volume and number in rat epididymal fat.

Data calculated using the results presented in Tables 1-4. 
\# parameter

E1 initial WAT weight (minus debris)

E2 adipocytes

E3 red blood cells

E4 nucleated stromal cells

E5 total cells

E6 extracellular space

E7 fat

E8 total stromal cell volume

E9 total nucleated cell volume

E10 adipocyte non-fat cell volume

$\begin{array}{ccccl}\begin{array}{c}\text { volume } \\ \mu \mathrm{L} / \mathrm{g}\end{array} & \begin{array}{c}\text { \% of } \\ \text { WAT } \\ \text { volume }\end{array} & \begin{array}{c}\text { cells }\left(10^{6} / \mathrm{g}\right. \\ \text { WAT })\end{array} & \begin{array}{c}\text { \% of } \\ \text { WAT } \\ \text { cells }\end{array} & \text { calculations } \\ 976 & 100.0 & & & \text { B4 } \\ 878 & 90.0 & 1.85 & 7.2 & \text { D1 } \\ 0.44 & 0.05 & 17.0 & 66,2 & \text { C7 } \\ 1.87 & 0.19 & 6.84 & 26.6 & \text { C8 } \\ 880 & 90.2 & 25.7 & 100.0 & \text { E2 }+ \text { E3 }+ \text { E4 } \\ 96 & 9.8 & & & \text { E1 }- \text { E5 } \\ 865 & 88.6 & & & \text { D2 } \\ 2.3 & 0.24 & & & \text { C6 } \\ 880 & 90.2 & & & \text { E2 }+ \text { E4 } \\ 13.0 & 1,3 & & & \text { D3 }\end{array}$




\section{Table 6(on next page)}

Characteristics of the adipocytes isolated from rat epididymal adipose tissue

Data calculated using the results shown in Tables 1-3. 
\# parameter

F1 lipid content

F2 cell lipid weight

F3 cell lipid volume

F4 cell mean volume

F5 non-fat cell volume units values calculations

$\mathrm{mg} / \mathrm{g} \quad 797 \quad$ B5

$\mathrm{ng} /$ cell $\quad 431 \quad \mathrm{~B} 5 /\left(\mathrm{C} 1 \times 10^{6}\right)$

$\mathrm{pL} /$ cell $\quad 468 \quad(\mathrm{~B} 5 / \mathrm{C} 1) \times 10^{6} / \mathrm{dl}$

$\mathrm{pL} / \mathrm{cell}$

475

A11

$\mathrm{pL} / \mathrm{cell}$

$13 \quad \mathrm{~F} 4-\mathrm{F} 3$ 
Figure 1

Representative microphotography of an adipocyte preparation observed at the microscope using a Neubauer chamber

The squares in the grid have a width of $250 \mu \mathrm{m}$, and correspond to a volume of $6.25 \mathrm{~nL}$

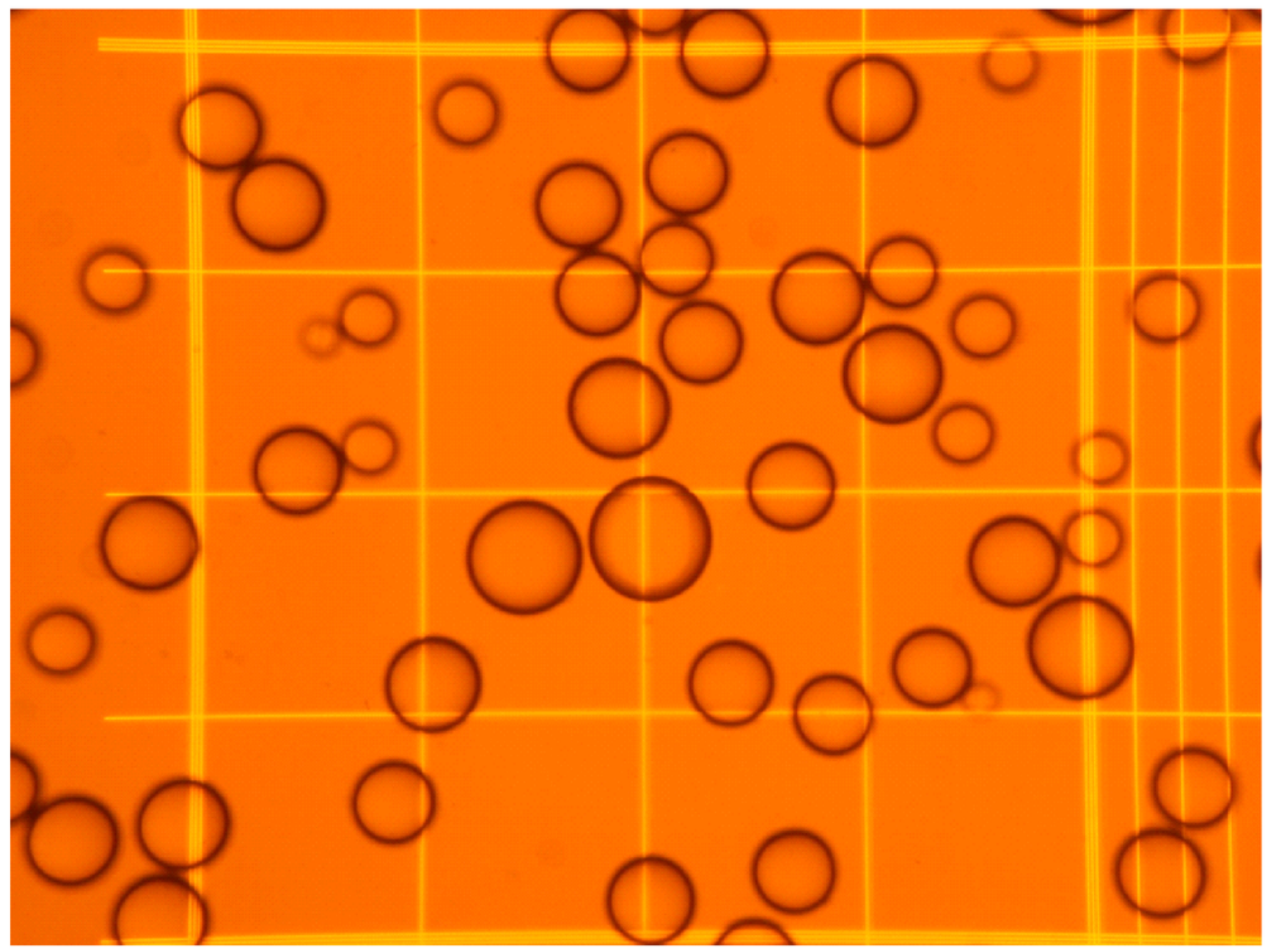


Figure 2

Representative graph of cell size (diameter, volume) vs. cell numbers representation obtained applying the cell extraction procedure described in the text to a sample of epididymal adipose tissue

The data have been grouped to facilitate the presentation. The arrow (and the number above) represent the mean cell diameter and volume. The horizontal lines represent each one the extent of one sd. 

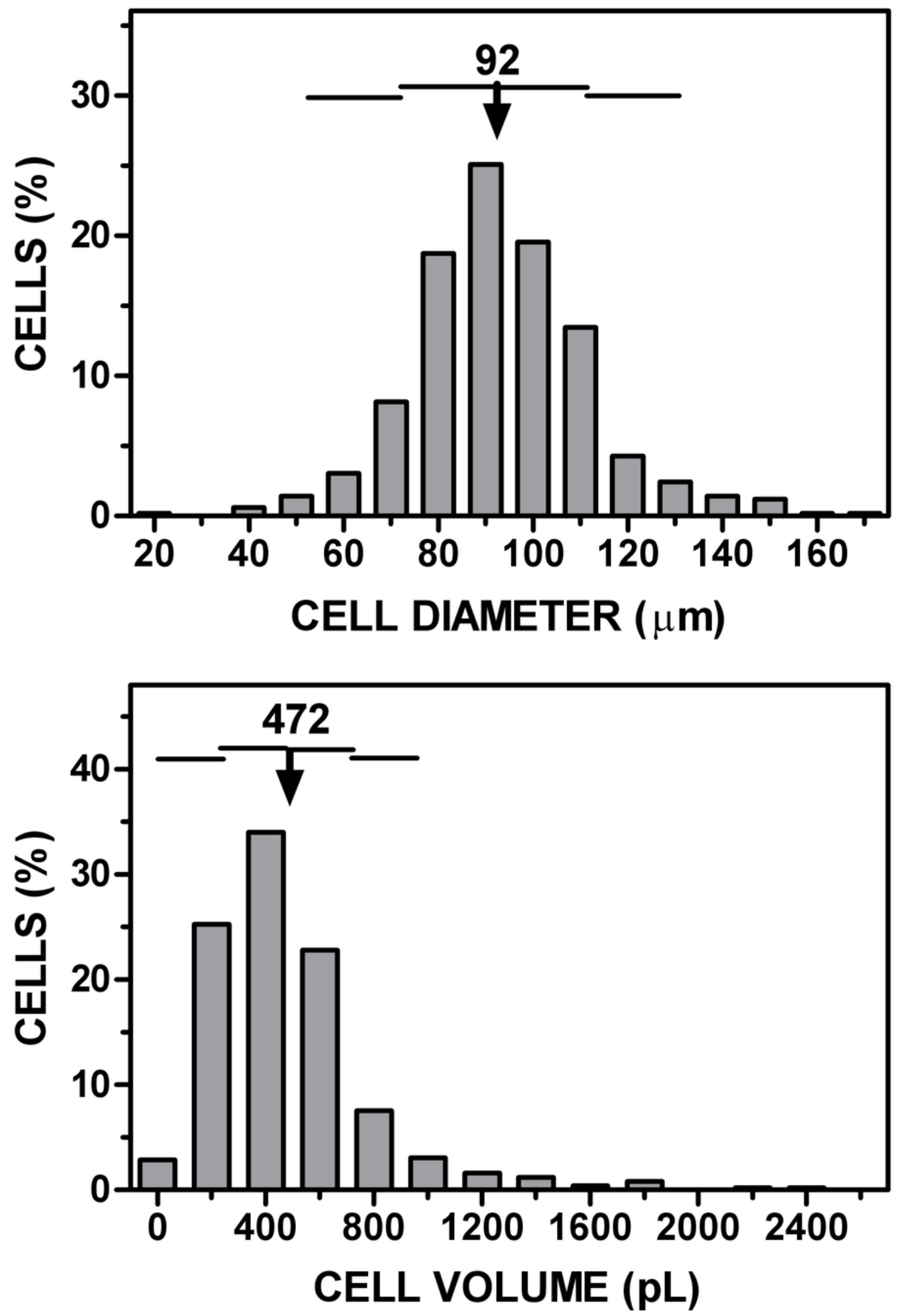


\section{Figure 3}

Representative graph of flow cell analysis of stromal fraction of epididymal rat WAT to discriminate nucleated from non-nucleated cells.

Both propidium lodide (IP) and Syto-13 (SYTO) bind DNA-positive and double positive particles (i.e. cells). The dots in the upper and right areas correspond to nucleated stromal cells; dots in the lower-left square show the unstained cells, largely corresponding to the high proportion of erythrocytes. 


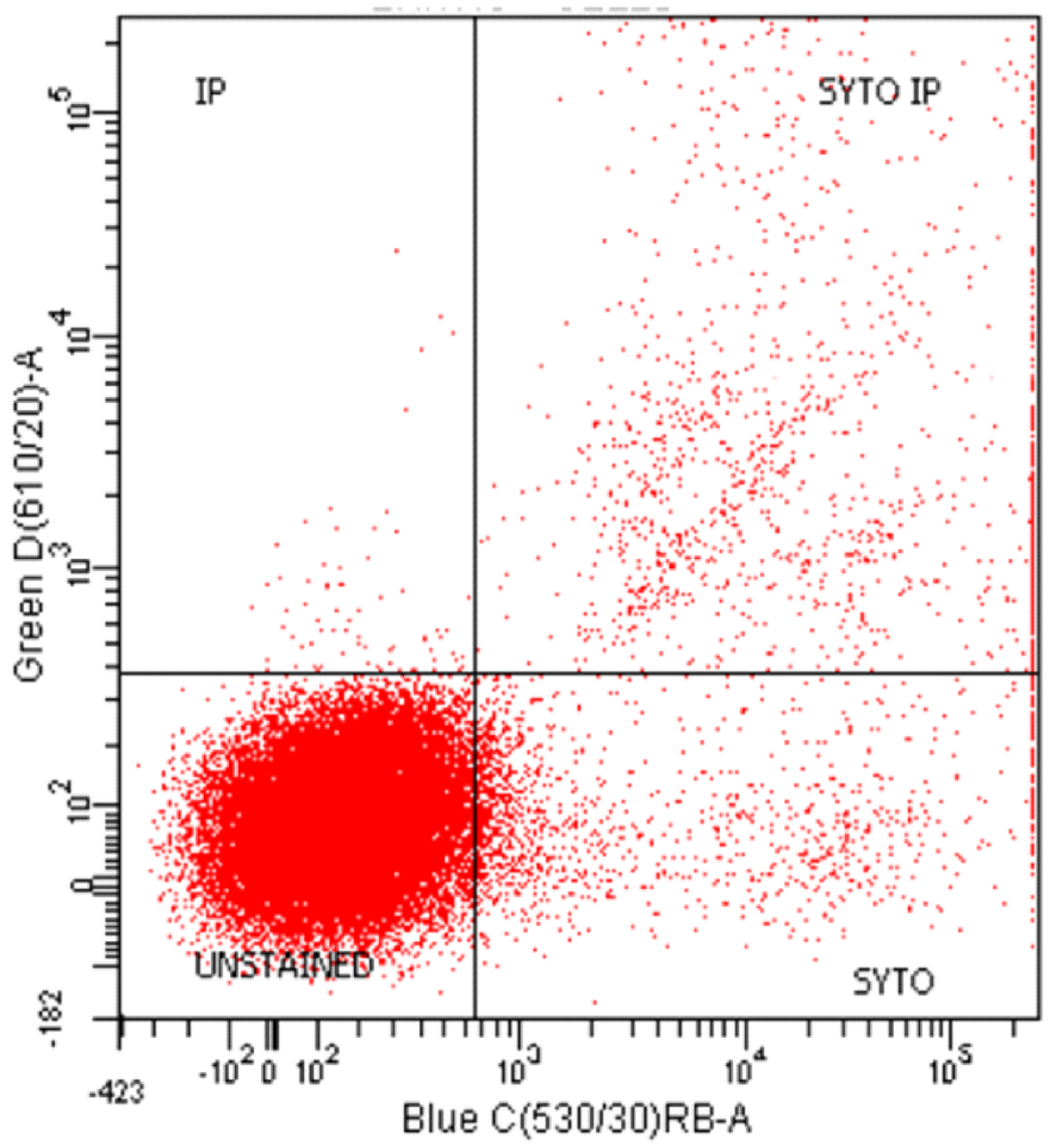




\section{Figure 4}

Metabolic activity of epididymal WAT adipocytes in primary culture at $24 \mathrm{~h}$ and $48 \mathrm{~h}$ of incubation

The data represent the mean \pm sd of four different rats (triplicate wells). The data are presented as rates of uptake (glucose, white bars), or efflux to the medium (lactate, blue bars, glycerol red bars and NEFA beige bars), in concordant units (akat/cell) to facilitate comparisons. Statistical significance of the differences between $24 \mathrm{~h}$ and $48 \mathrm{~h}$ data: an asterisk * represents a $\mathrm{P}<0.05$ difference (Student's $t$ test).

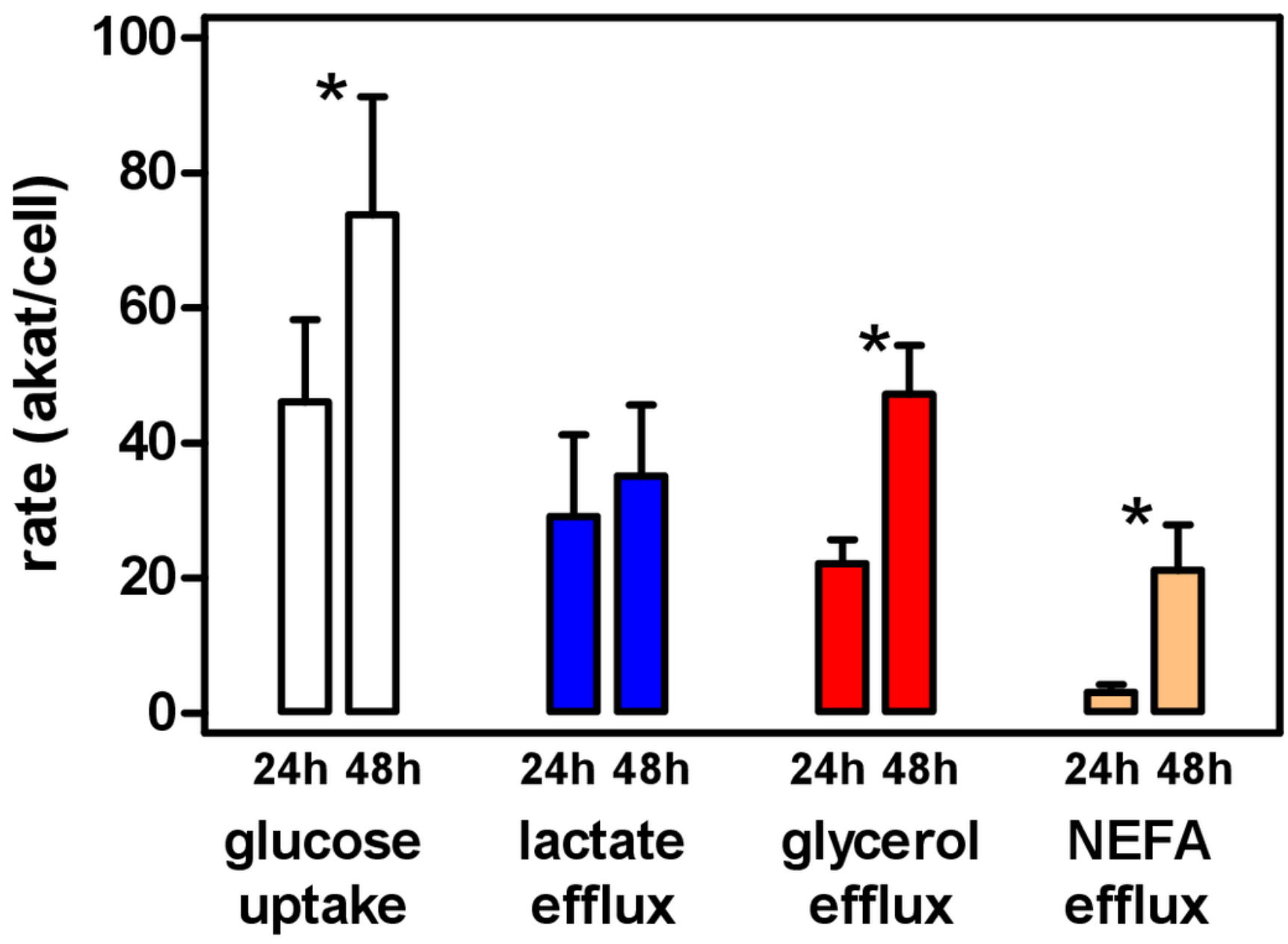

